\title{
KINETICS OF PASSIVATION AND PITTING CORROSION OF POLYCRYSTALLINE COPPER IN BORATE BUFFER SOLUTIONS CONTAINING SODIUM CHLORIDE
}

\author{
M. R. G. De Chialvo, R. C. Salvarezza, D. Vasquez Moll and A. J. Arvia \\ Instituto de Investigaciones Fisicoquimicas Teóricas y Aplicadas-INIFTA, Casilla de Correo 16, Sucursal 4, \\ 1900 I a Plata, Argentina
}

(Received 26 February 1985; in revised form 22 April 1983)

\begin{abstract}
The pitting corrosion of copper in borate buffer containing sodium chloride is studied by using potentiostatic and potentiodynamic techniques complemented with scanning electron microscopy and EDAX. The breakdown potential shifts towards more negative values as the sodium chloride concentration increases. During pitting both soluble $\mathrm{Cu}(\mathrm{I})$ and $\mathrm{Cu}(\mathrm{II})$ species are detected. The first stage of pitting is explained through the competition bet ween the passive layer formation and the nucleation and growth of the $\mathrm{CuCl}$ layer in equilibrium with $\mathrm{Cu}(\mathrm{I})-\mathrm{chloride}$ complexes in solution. When salt nuclei reach the metal surface, pit growth under charge-transfer control is found. In the following stage the kinetics of pit growth changes to a difTusion controlled provess when the thick $\mathrm{CuCl}$ layer is completed. Secondary breakdown of the salt layer results in copper dissolution through $\mathrm{Cu}$ (II) soluble species. The corresponding overall process is discussed in terms of a sum of nucleation and growth processes. The reaction model reproduces the potentiostatic current transients of copper in weakly alkaline borate buffer containing sodium chloride.
\end{abstract}

\section{INTRODUCTION}

The corrosion and passivation of copper have been studied over a wide range of experimental conditions[1]. In the absence of aggressive anions, the passivation of copper in alkaline solution is due to an oxide layer whose electrochemical characteristics and structure depends considerably on the solution composition and applied potential[2]. Potentiodynamic polarization curves exhibit various anodic peaks assigned to the formation of $\mathrm{Cu}(\mathrm{I}), \mathrm{Cu}(\mathrm{II})$ and $\mathrm{Cu}$ (III) species and a multiplicity of cathodic peaks related to the electroreduction of different soluble and insoluble copper-containing species[3]. The structure of the passive layer as revealed by ESCA and ISS in borate buffers consists of an inner $\mathrm{Cu}_{2} \mathrm{O}$ and outer $\mathrm{CuO}$ hydrated layers [4]. During the anodization of copper in neutral and alkaline solutions both soluble $\mathrm{Cu}(\mathrm{I})$ and $\mathrm{Cu}(\mathrm{II})$ species have been detected through the rrde technique $[3,5]$.

The electrochemical behaviour of copper in solutions containing aggressive anions has been also extensively investigated in acid and weakly acid solutions [6-8]. Anodic potentiostatic transients for the electrodissolution of shielded horizontal $\mathrm{Cu}$ electrodes in aqueous $\mathrm{HCl}$ were quantitatively compared to Mueller's theory of passivation[9-11]. The anodic transient exhibits a first current plateau which is related to the following reaction:

$$
\mathrm{Cl}^{-}+\mathrm{Cu} \rightarrow \mathrm{CuCl}+e^{-}
$$

where the anodic layer of $\mathrm{CuCl}$ passivates the electrode. The process is convection free for rapid transients. The anodic transients present also a second plateau which corresponds to a complex ion formation as $\mathrm{CuCl}$ is dissolved as $\mathrm{CuCl}_{2}^{-}$and $\mathrm{CuCl}_{3}^{-}$. In this case, the electrodissolution process is controlled by the diffusion of the complex ions out of the electrode surface. This process is followed by $\mathrm{CuCl}$ precipitation to form a thick layer on the electrode.

Secondary breakdown of the $\mathrm{CuCl}$ layer results in pitting corrosion of copper[12]. At pH values close to 9.00 in the presence of $\mathrm{Cl}^{-}$ions, the passive oxide film is formed on the copper surface previous to its breakdown and pit growth[13]. Breakdown potentials, corrosion products inside the pits and $\mathrm{pH}$ effects on the pitting process are also reported $[13,14]$.

A general survey of the literature on the corrosion and passivation of copper in aqueous solutions indicates that the information on the processes leading to passivity breakdown and pit growth are considerably more scarce than that available for other metals such as iron, nickel and ferrous alloys.

The present paper deals with the competition between the onset of passivity promoted by water and $\mathrm{OH}^{-}$ions and the formation of a $\mathrm{CuCl}$ layer and its intluence on the pitting corrosion of copper in weakly alkaline borate buffer (pH 9.00) in the presence of $\mathrm{NaCl}$. The pitting process is studied by using conventional electrochemical texhuiques, scanning electron microscopy and EDAX. The kinetics of pit initiation and growth are discussed through the nucleation and growth theory as applied to the interpretation of the pitting corrosion of iron and nickel in aqueous solutions $[15,16]$.

\section{EXPERIMENTAL}

The working electrodes were made of polycrystallinc $99.9 \%$ copper rods axially embedded in Araldite holders to obtain exposed circular areas of $0.072 \mathrm{~cm}^{2}$ ready to be mounted in a rotating disc electrode device. The pretreatment of each specimen consisted of a 
gradual polishing starting with fine-grained emery paper followed with diamond paste and finally with alumina paste $(1 \mu \mathrm{m}$ diam.). The polished specimen was successively rinsed with acetone A.R., twicedistilled water, and finally dried in air at room temperature. A fresh specimen was used for each run. The potential of the specimen was measured against a saturated calomel electrode (sce) provided with a Luggin-Haber capillary tip. A platinum plate was used as counterelectrode. The three electrodes werc mounted in a conventional Pyrex glass cell. Measurements were made at $25 \pm 0.1^{\circ} \mathrm{C}$ in the borate boric acid buffers at $\mathrm{pH} 9.00\left[0.075 \mathrm{Na}_{2} \mathrm{~B}_{4} \mathrm{O}_{7}+0.15 \mathrm{M} \mathrm{H}_{3} \mathrm{BO}_{3}\right.$ $\left.+x c_{\mathrm{NaCl}}(0 \leqslant x \leqslant 1 \mathrm{M})\right]$. Solutions were prepared from twice-distilled water and A.R. chemicals and purged with purified nitrogen for $3 \mathrm{~h}$ previous to each run.

Singular triangular potential sweep (stps) voltammograms between the cathodic $\left(E_{s, c}\right)$ and the anodic $\left(E_{s, a}\right)$ switching potential at the sweep rates $(v) 0.02$, 0.002 and $0.00016 \mathrm{~V} \mathrm{~s}^{-1}$ were recorded in the apparent current density $(j)$ vs potential $(E)$ scale. The ring-disc technique (rrde) was used to detect soluble copper ionic species formed during electrooxidation of copper to either $\mathrm{Cu}(\mathrm{I})$ or $\mathrm{Cu}(\mathrm{II})$. For this purpose a gold ring $\left(0.035 \mathrm{~cm}^{2}\right.$ apparent area) copper disc $\left(0.125 \mathrm{~cm}^{2}\right.$ apparent area) rotating electrode was used (collection efficiency 0.25 ) at rotation speeds $(\omega)$ in the $250<\omega$ $<3000 \mathrm{rpm}$ range. Current transients $(I / t)$ at constant potential $\left(E_{s}\right)$ were also recorded. In this case, preceding the application of the potential step at $E_{s}$, the working electrode was held firstly at $-1.2 \mathrm{~V}\left(E_{c}\right)$ for $90 \mathrm{~s}$ and later at $-0.10 \mathrm{~V}\left(E_{a}\right)$ for $90 \mathrm{~s}$ to form a thin $\mathrm{Cu}_{2} \mathrm{O}$ layer in the order of $\mathrm{ca} 10 \mathrm{~A}$ thickness[4]. SEM observations and EDAX data were also obtained.

\section{RESULTS}

1. Potentiodynamic polarization curves in the borax buffer

Potentiodynamic curves of polycrystalline copper in borax buffer ( $\mathrm{pH} 9.00)$ recorded at $0.002 \mathrm{~V} \mathrm{~s}^{-1}$ (Fig. 1) show between $E_{s, c}=-1.00 \mathrm{~V}$ and $E_{s, a}=0.80 \mathrm{~V}$ two

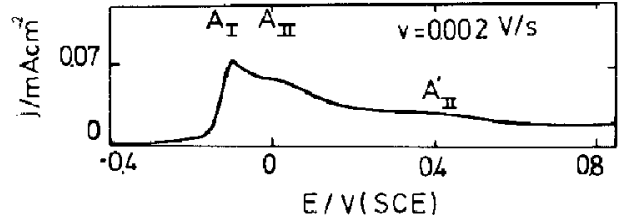

Fig. 1. Potentiodynamic polarization curve of copper in the borax buffer solution at $0.002 \mathrm{~V} \mathrm{~s}^{-1} ; 25^{\circ} \mathrm{C}$.

anodic pcaks at $-0.10 \mathrm{~V}$ (peak $A_{1}$ ) and $0.00 \mathrm{~V}$ (peak $A_{\mathrm{II}}$ ) and at $E_{s}>E_{A_{1}}$ a passive region containing a broad hump at $0.40 \mathrm{~V}$ (peak $A_{\mathrm{HI}}^{\prime}$ ). After cycling at 0.02 $V^{-1}$ until the voltammogram remains unchanged, the stabilized $E / j$ profile shows only a single peak (peak $A$ ) at $0.03 \mathrm{~V}$ instead of peaks $A_{1}$ and $A_{\mathrm{II}}$ and peak $A_{\mathrm{II}}^{\prime}$ at $0.60 \mathrm{~V}$. The potential scan in the negative direction presents two cathodic peaks at $-0.30 \mathrm{~V}$ (peak $C_{\mathrm{II}}$ ) and $-0.44 \mathrm{~V}$ (peak $C_{\mathrm{I}}$ ). Inspection of the voltammogram resulting when $E_{s, a}$ is stepwise changed from -0.20 to $0.80 \mathrm{~V}$ shows that the pairs of peaks $A_{1}$ and $C_{1}$, and $A_{\mathrm{II}}\left(A_{\mathrm{II}}^{\prime}\right)$ and $C_{\mathrm{II}}$ are complementary peaks [Fig, 2(a)]. Peak $A_{\mathrm{I}}$ is assigned to the electroformation of $\mathrm{Cu}_{2} \mathrm{O}$ while peak $A_{\text {II }}$ is related to the electroformation of either $\mathrm{CuO}$ or $\mathrm{Cu}(\mathrm{OH})_{2}$. From ESCA and ISS one concludes [4] that the film produced at $E_{s}>E_{A_{I I}}$ consists of an inner $\mathrm{Cu}_{2} \mathrm{O}$ layer and an outer $\mathrm{CuO}$ or $\mathrm{Cu}(\mathrm{OH})_{2}$ layer. This complex structured layer is electroreduced in two consecutive steps to $\mathrm{Cu}(\mathrm{I})$ and to copper at the potential ranges of current peaks $C_{11}$ and $C_{\mathrm{l}}$, respectively. From the rtps run at $0.10 \mathrm{Vs}^{-1}$ between $E_{s, a}=-1.00 \mathrm{~V}$ and $E_{s, c}=-0.20 \mathrm{~V}$ it is concluded that the current contribution at the negative side of peak $A$ involves a small peak (peak $A_{1}^{\prime}$ ) at $-0.36 \mathrm{~V}$ whose conjugated cathodic contribution appears at $-0.65 \mathrm{~V}$ [Fig. 2(b)]. The charge density related to peaks $A_{\mathrm{f}}^{\prime}$ and $\vec{C}_{\mathrm{l}}^{\prime}$, which is estimated as $0.3 \mathrm{mC} \mathrm{cm}^{-2}$, can be assigned to the electroformation and electroreduction of a $\mathrm{Cu}(\mathrm{OH})_{\mathrm{ad}}$ monolayer [17] at potentials slightly more negative than the equilibrium potential of the $\mathrm{Cu} / \mathrm{Cu}_{2} \mathrm{O}$ electrode (Table 1).

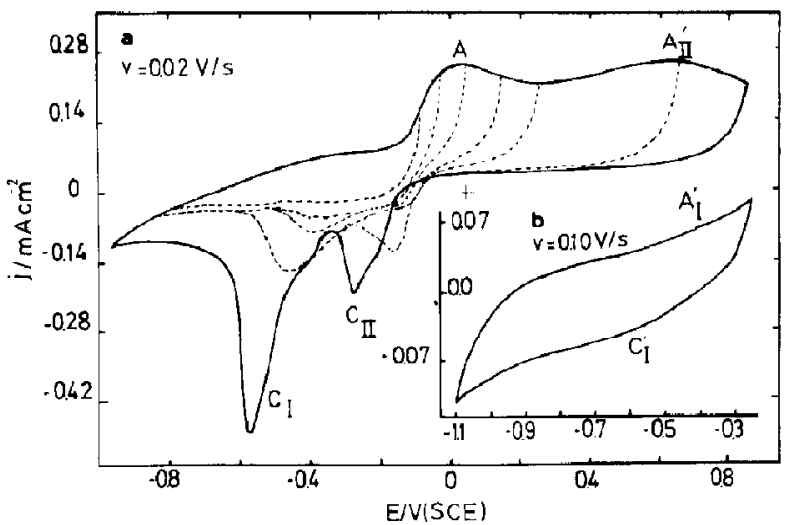

Fig. 2. (a) Stabilized voltammogram of copper in the borax buffer solution at $0.02 \mathrm{Vs}^{-1}$; (b) at $0.10 \mathrm{~V} \mathrm{~s}^{-1} ; 25^{\circ} \mathrm{C}$. 
Table 1. Standard equilibrium potentials (us sce) of redox processes related to copper in base solutions containing chloride jons $[4,29]$

\begin{tabular}{lc}
\multicolumn{1}{c}{ Reaction } & $E^{\circ} / \mathrm{V}$ \\
\hline $\mathrm{Cu}+\mathrm{Cl}^{-} \rightarrow \mathrm{CuCl}+e^{-}$ & -0.105 \\
$\mathrm{Cu}+2 \mathrm{Cl}^{-} \rightarrow \mathrm{CuCl}_{2}^{-}+e^{-}$ & -0.0324 \\
$\mathrm{Cu}+\mathrm{Cl}^{-} \rightarrow \mathrm{CuCl}_{3}^{2}+e^{-}$ & -0.0442 \\
$2 \mathrm{Cu}+\mathrm{H}_{2} \mathrm{O} \rightarrow \mathrm{Cu}_{2} \mathrm{O}+2 \mathrm{H}^{+}+2 e^{-}$ & 0.217 \\
$\mathrm{Cu}_{2} \mathrm{O}+3 \mathrm{H}_{2} \mathrm{O} \rightarrow 2 \mathrm{Cu}(\mathrm{OH})_{2}+2 \mathrm{H}^{+}+2 e^{-}$ & 0.487 \\
$\mathrm{Cu}_{2} \mathrm{O}+\mathrm{H}_{2} \mathrm{O}=2 \mathrm{CuO}+2 \mathrm{H}^{+}+2 e^{-}$ & 0.427 \\
\hline
\end{tabular}

\section{Potentiodynamic polarization curves in the borax} buffer containing $\mathrm{NaCl}$

The addition of $\mathrm{NaCl}$ to the borax buffer increases the heights of peaks $A_{1}$ and $A_{\text {II }}$ proportionally to $c_{\mathrm{NaCl}}$ $\left(0.1 \leqslant c_{\mathrm{NaCl}} \leqslant 1 \mathrm{M}\right)$. For $c_{\mathrm{NaCl}} \geqslant 0.5 \mathrm{M}$ a new current peak (peak $A_{\mathrm{III}}$ ) is observed at ca $0.00 \mathrm{~V}$ (Fig. 3). At a constant $c_{\mathrm{NaCl}}$ the heights of peaks $A_{\mathrm{I}}, A_{\mathrm{II}}$ and $A_{1 \mathrm{II}}$ increase according to $\omega$, although the greatest infuence of $\omega$ appears on $A_{11}$. The passive current also increases as $c_{\mathrm{NaCl}}$ increases. The $E / j$ profiles exhibit an abrupt increase in the anodic current when a critical potential value $\left(E_{b}\right)$ is exceeded. The rapid current increase is preceded by current oscillations probably related to the activation-repassivation processes occurring at the $\mathrm{Cu}$ electrode. The current increase at potentials greater then $E_{b}$ is associated with film breakdown and pitting corrosion of copper.

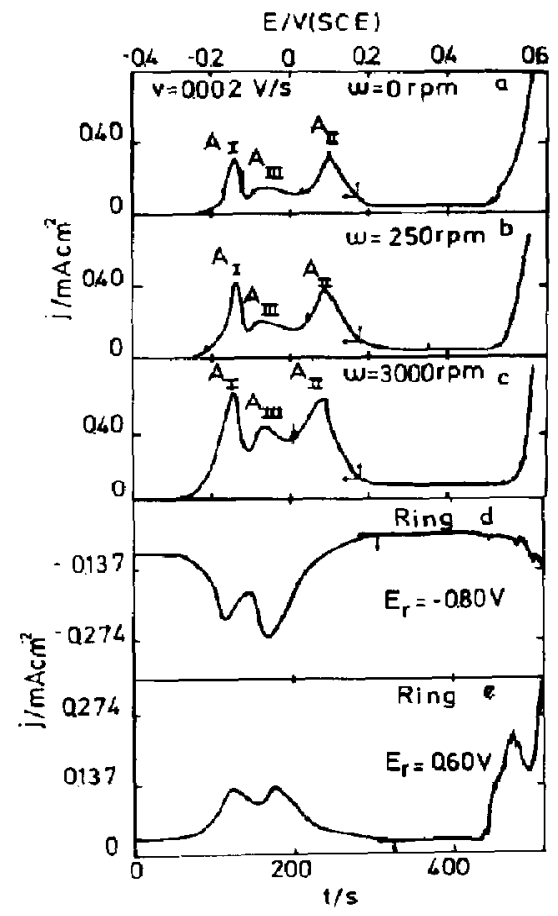

Fig. 3. Voltammograms of copper rotating disc electrode in borax buffer $+0.5 \mathrm{M} \mathrm{NaCl}$ solution at $0.002 \mathrm{~V} \mathrm{~s}^{-1}$. (a) $\omega=0$ rpm; (b) $\omega=250 \mathrm{rpm}$; (c) $\omega=3000 \mathrm{rpm}$; (d) current at the rotating ring electrode, $E_{\mathrm{r}}=-0.80 \mathrm{~V}, \omega=3000 \mathrm{rpm}$; (e) current at the rotating ring electrode, $E_{r}=0.60 \mathrm{~V}, \omega$ $=3000 \mathrm{rpm} ; 25^{\circ} \mathrm{C}$.

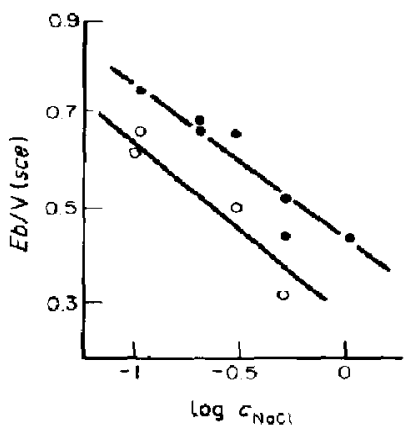

Fig. 4. $E_{b} v s \log \mathrm{NaCl}$ concentration plot. Data obtained at $0.002 \mathrm{Vs}^{-1}(0)$ and $0.00016 \mathrm{Vs}^{-1}(e) ; 25^{\circ} \mathrm{C}$.

Simultaneously, white-orange spots appear on the electrode surface. The increase in the $\mathrm{NaCl}$ concentration shifts $E_{b}$ towards more negative values according to the following equation (Fig- 4):

$$
E_{b}=a-b^{\prime} \log c_{\mathrm{NaCl}}
$$

where $a$ and $b^{\prime}$ are constants whose values depend on $v$ (Fig. 4). Otherwise as $v$ decreases $E_{b}$ becomes more negative, and as $\omega$ increases from 0 to $3000 \mathrm{rpm}$, a shift in $E_{b}$ of about $30 \mathrm{mV}$ in the positive potential direction is noticed (Fig. 3). Voltammograms recorded at $0.002 \mathrm{Vs}^{-1}$ between $E_{s, c}=-0.10 \mathrm{~V}$ and $E_{s, a}>E_{b}$ after $90 \mathrm{~s}$ at $E_{s, c}$ to form a $\mathrm{Cu}_{2} \mathrm{O}$ prepassive layer (Fig. 5), show the typical behaviour of a nucleation and growth process. During potential scan in the negative direction the current is higher than that observed in the reverse scan. At potentials close to $0.0 \mathrm{~V}$ pit repassivation is observed.

Voltammograms at $0.02 \mathrm{Vs}^{-1}$ in the borax buffer $+0.5 \mathrm{M} \mathrm{NaCl}$ (Fig. 6) run between $E_{s, c}=-1.00 \mathrm{~V}$ and $E_{s, c}$ values gradually changed from -0.25 to $0.40 \mathrm{~V}$, exhibit practically no change in peaks $A_{1}^{\prime}$ and $C_{\text {I }}^{\prime}$, but the reaction corresponding to peak $A_{\mathrm{III}}$ appeurs at potentials closer to the equilibrium potential of the $\mathrm{Cu} / \mathrm{CuCl}\left(c_{\mathrm{NaCl}}=0.5 \mathrm{M}\right)$ (Table 1). However, the corresponding cathodic contribution is found at potentials more negative than those reported in acid $\mathrm{LiCl}$ $1 \mathrm{M}$ [18]. In these cases the charges of peaks $C_{1 \mathrm{II}}$ and $C_{\mathrm{I}}$ overlap to a great extent. This fact suggests that the $\mathrm{CuCl}$ electroreduction becomes more difficult when the inner $\mathrm{Cu}_{2} \mathrm{O}$ layer is already formed.

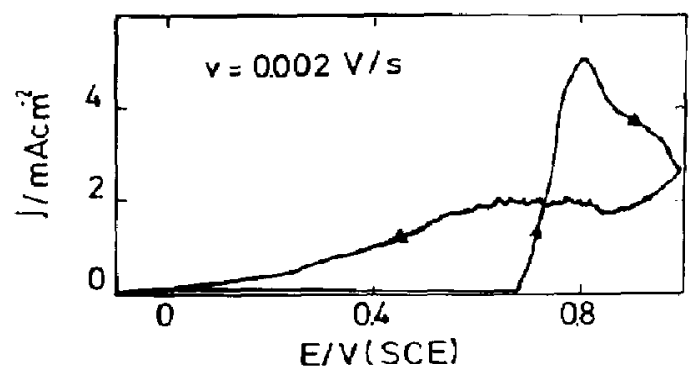

Fig. 5. Voltammograms of copper in borax buffer $+0.2 \mathrm{M}$ $\mathrm{NaCl}$ solution at $0.002 \mathrm{~V} \mathrm{~s}^{-1}$, after a previous anodizing at $-0.10 \mathrm{~V}$ for $90 \mathrm{~s} ; 25^{\circ} \mathrm{C}$. 


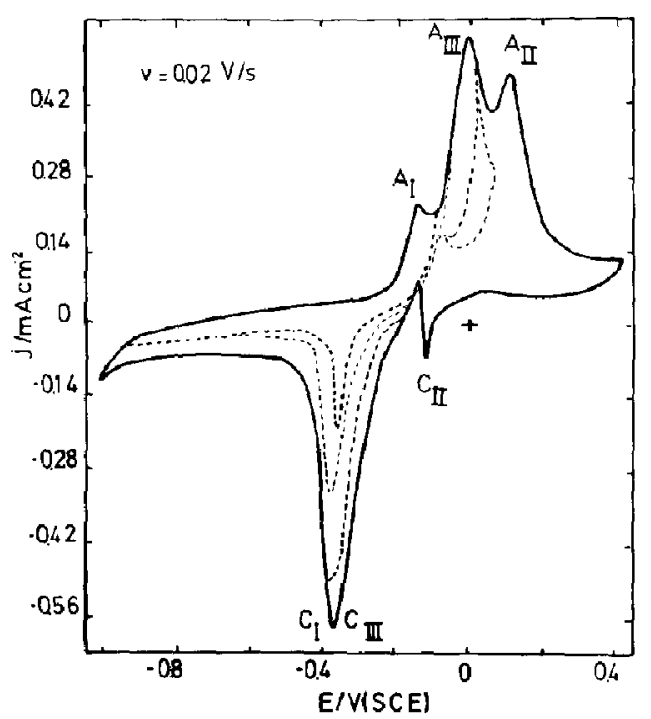

Fig. 6. Stabilized voltammograms of copper in borax buffer $+0.5 \mathrm{M} \mathrm{NaCl}$ solution at $0.02 \mathrm{~V} \mathrm{~s}^{-1} ; 25^{\circ} \mathrm{C}$

In the presence of $\mathrm{NaCl}$ peaks $A_{\mathrm{II}}$ and $C_{\mathrm{II}}$ appear at potentials more positive than in free $\mathrm{NaCl}$ solution. In this case during the negative-direction potential scan when the electroreduction of $\mathrm{Cu}(\mathrm{OH})_{2}$ occurs, an anodic current is detected which suggests that in the $\mathrm{NaCl}$-containing solutions the passive state is mainly due to the electroformation of the $\mathrm{Cu}(\mathrm{OH})_{2}$ layer.

Data obtained with the rrde technique by applying to the disc a potential sweep of $0.002 \mathrm{Vs}^{-1}$ and kecping the ring potential at $-0.80 \mathrm{~V}$ to electroreduce any $\mathrm{Cu}(\mathrm{I})$ and $\mathrm{Cu}$ (II) species, is consistent with the presence of soluble copper species at potentials preceding peaks $A_{1}$ and $A_{\text {III }}$ as well as in the pitting region[Fig. 3(d)]. Similar experiments were made by holding the ring at $0.60 \mathrm{~V}$ to detect only soluble $\mathrm{Cu}(\mathrm{I})$ species[Fig. 3(e)]. The latter is detected at potentials preceding those of peaks $A_{1}$ and $A_{\text {III }}$ and also during
Table 2. Amounts of soluble copper(I) species detected at current peak $A_{1}-A_{\text {III }}$

\begin{tabular}{crc}
\hline$c_{\mathrm{NaC}} / \mathrm{M}$ & $q / \mu \mathrm{C} \mathrm{cm}^{-2}$ & \multicolumn{1}{c}{$\omega / \mathrm{rpm}$} \\
\hline 0 & 24.5 & 250 \\
0.1 & 282.0 & 250 \\
0.5 & 11222.0 & 250 \\
0.5 & 19815.0 & 3000 \\
\hline
\end{tabular}

pitting. However, in the pitting region, the amount of soluble $\mathrm{Cu}(\mathrm{II})$ is greater than that of soluble $\mathrm{Cu}(\mathrm{I})$ species. The latter in the potential range of peak $A_{\mathrm{I}}$ increases according to the $\mathrm{NaCl}$ concentration and to $\omega$. This fact indicates that $\mathrm{Cu}(\mathrm{I})$ in solution undergoes a reaction with $\mathrm{Cl}^{-}$ions yielding $\mathrm{CuCl}_{2}^{-}$in equilibrium with insoluble $\mathrm{CuCl}$ (s) (Table 2).

\section{Current transients in the borax buffer}

Current transients in the borax buffer at different potential steps $\left(E_{s}\right)$ were run after following a two-step procedure, namely the electrode was firstly held at $-1.20 \mathrm{~V}$ for $90 \mathrm{~s}$ to electroreduce the copper surface, and then at $-0.10 \mathrm{~V}$ for another $90 \mathrm{~s}$ to form a thin prepassive $\mathrm{Cu}_{2} \mathrm{O}$ layer of approx. $10 \AA$ thickness[4]. Immediately afterwards the electrode was stepped to $E_{s}$ and the corresponding current transient was recorded[Fig. $7(\mathrm{a})]$. In the $0.20 \leqq E_{s} \leqq 0.80 \mathrm{~V}$ range the current decreases monotonously to reach the corresponding stationary passivity current value and this behaviour is independent of $\omega$. The charge resulting from the current transient integration for $E_{s}>E_{A_{11}}$ is associated with two main processes, namely the formation and growth of the passive layer $\left(j_{p}\right)$ and the corrosion of copper through the passive layer $\left(j_{c}\right)$. The latter implies the formation of soluble copper species as detected through the use of the rrde. Practically all soluble species resulting during the potential step from the prepassive $(E=-0.10 \mathrm{~V})$ to the passive region correspond to soluble $\mathrm{Cu}(\mathrm{II})$ probably as $\mathrm{Cu}(\mathrm{OH})_{2}^{-}$(l) species[8] (Fig. 8).

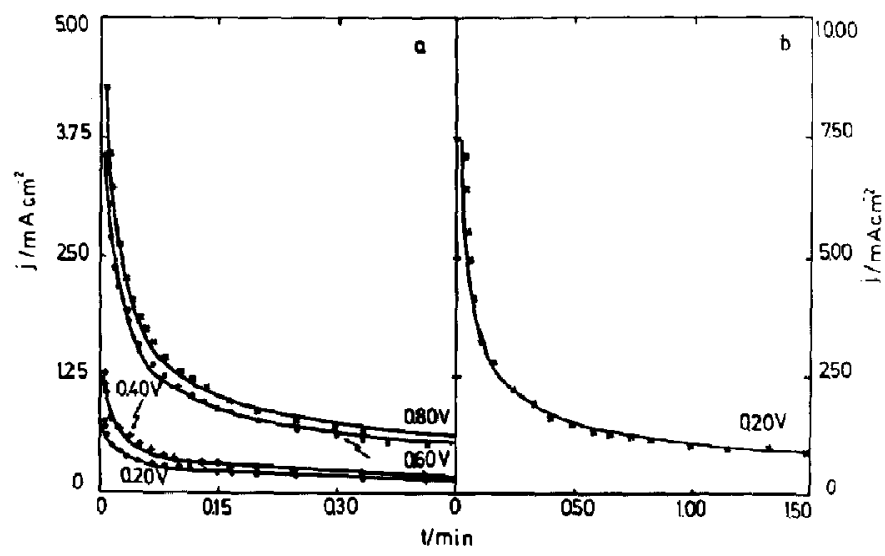

Fig. 7. (a) Current transients in borax buffer solution at different $E$, values; (b) current transient recorded in the borax buffer $+0.5 \mathrm{M} \mathrm{NaCl}$ solution at $E_{\mathrm{s}}<E_{\mathrm{b}}\left(E_{\mathrm{s}}=0.20 \mathrm{~V}\right) ; 25^{\circ} \mathrm{C}$. 


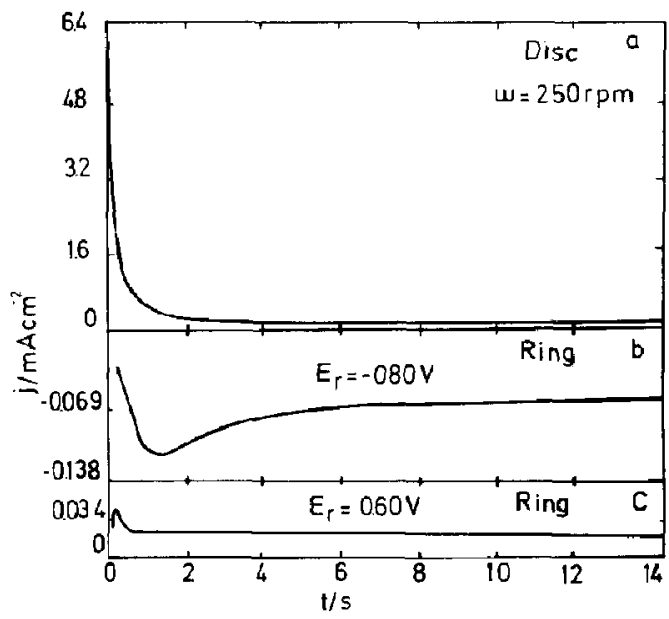

Fig. 8. (a) Current transient in the borax buffer solution at $E_{s}=0.20 \mathrm{~V}$; (b) current density at the rotating ring electrode $E_{r}=-0.80 \mathrm{~V}$; (c) current density at the rotating ring electrode $E_{\mathrm{r}}=0.60 \mathrm{~V}$.

\section{Current transients in the barax buffer containing $\mathrm{NaCl}$}

Current transients recorded in borax buffer $+0.5 \mathrm{M}$ $\mathrm{NaCl}$ at $E_{s}<E_{b}$ exhibit characteristics rather similar to those described for plain borax solution, although the instantaneous current becomes greater than that resulting in the absence of $\mathrm{NaCl}$ [Fig. 7(b)]. This fact is accompanied by a greater production of soluble $\mathrm{Cu}(\mathrm{II})$.

In the $0.20 \leqq E_{s} \leqq E_{b}$ potential range only minor amounts of $\mathrm{Cu}$ (I) soluble species are caught at the ring electrode. On the other hand, the current transient recorded for $E_{s}>E_{b}$ [Fig. $\left.9(\mathrm{a})\right]$ initially decreases to a minimum $\left(I_{m}\right)$ and after certain time $\left(t_{i}\right)$ it rises to attain a maximum $\left(I_{M}\right)$ at the time $t_{M}$. Finally, it decreases again but slowly. The increase in $E_{s}$ results in a decrease of $t_{i}$, an increase of $I_{M}$ and a decrease of $t_{M}[$ Figs $10(a)-$ (c) $]$. At a constant $E_{s}$, the same effects are got by increasing $c_{\mathrm{NaCl}}$ (Fig. 11). The apparent pitting current density $\left(j_{t}-j_{c}\right)$ es time $(t)$ plot fits the Engell-Stolica equation (Fig. 12):

$$
\left(j_{i}-j_{c}\right)=k\left(t-t_{i}\right)^{b}
$$

where $j_{i}$ and $j_{\varepsilon}$ are the overall and the background apparent current densities, respectively; $k$ and $b$ are constants. For $t \rightarrow 0$ the values of $b$ are in the $1.37-2.00$ range and when $t$ increases beyond a certain transition time $\left(t_{t}\right)$ which depends on the applied potential, these values fall in the $0.5-1.0$ range. When the potential step applied to the disc is greater than $E_{b}\left(E_{s}>E_{b}\right)$ and the potential at the ring is kept at $-0.80 \mathrm{~V}$, then the current transient at the ring due to the formation of soluble copper species at the disc electrode, follows that at the disc electrode[Fig. 9(b)]. Notwithstanding, when the potential at the ring is $0.60 \mathrm{~V}$, the corresponding current first decreases to a minimum and later increases to a maximum before the current at the disc reaches a maximum. Finally, the quasi-steady current is attained at the ring earlier than at the disc[Fig. 9(c)].

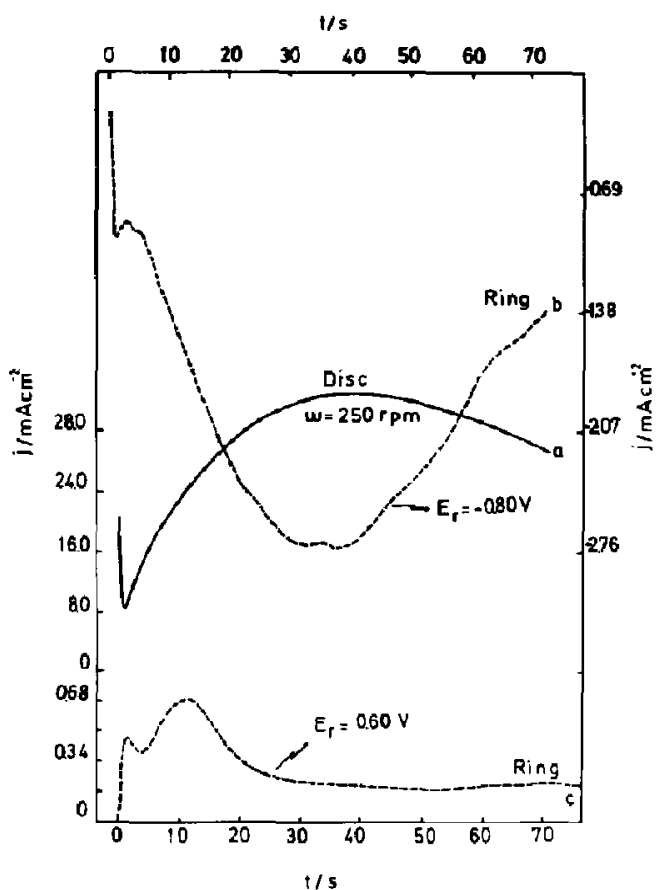

Fig. 9. (a) Current transient in borax buffer $+0.5 \mathrm{M} \mathrm{NaCl}$ solution at $E_{s}=0.50 \mathrm{~V}, \omega=250 \mathrm{rpm}$; (b) current at rotating ring electrode $E_{\mathrm{r}}=-0.80 \mathrm{~V}$; (c) current at the rotating ring electrode $E_{\mathrm{r}}=0.60 \mathrm{~V} ; 25^{\circ} \mathrm{C}$

The current densities of soluble $\mathrm{Cu}(\mathrm{I}),\left(j_{\mathrm{I}}\right)$ and $\mathrm{Cu}(\mathrm{II}),\left(j_{I I}\right)$, species detected at the ring can be estimated from the pitting apparent current density $\left(j_{t}-j_{c}\right)$ at the disc as follows:

$$
j_{1}=j_{r t}(0.60 \mathrm{~V})-j_{r c}(0.60 \mathrm{~V})
$$

and

$$
j_{\mathrm{II}}=\left[j_{r t}(-0.80 \mathrm{~V})-j_{r c}(-0.80 \mathrm{~V})\right]-\left[j_{\mathrm{I}}\right]
$$

where $j_{r r}$ and $j_{r c}$ are the total and background apparent current densities at the ring held at 0.60 and $-0.80 \mathrm{~V}$, respectively. From the different $\log$ apparent current densities vs time plots (Fig. 12) one concludes that the very initial stage of pit growth is mainly related to the formation of $\mathrm{Cu}(\mathrm{I})$ species. The transition in pit growth at $t_{t}$ implies $\mathrm{CuCl}$ precipitation in the pits and the secondary breakdown of the $\mathrm{CuCl}$ layers results in copper dissolution mainly as $\mathrm{Cu}$ (II) soluble species, which further contributes to the formation of a $\mathrm{CuCl}_{2}$ layer.

\section{SEM patterns and EDAX data}

SEM observations of copper electrodes held at $0.5 \mathrm{~V}$ for $50 \mathrm{~s}$ in borax buffer $+0.3 \mathrm{M} \mathrm{NaCl}$ show an outer $\mathrm{Cu}(\mathrm{OH})_{2}$ layer which spalls away from the electrode to the cell. After removing this non-adherent layer an inner layer showing a white-orange colour is observed. SEM patterns reveal the presence of a thick layer made of cubic crystals. The EDAX signals of these layers resulting when $E_{s}>E_{b}$ correspond to the presence of a $\mathrm{CuCl}$ layer. The layer is discontinuous at points where hemispherical pits are formed. 

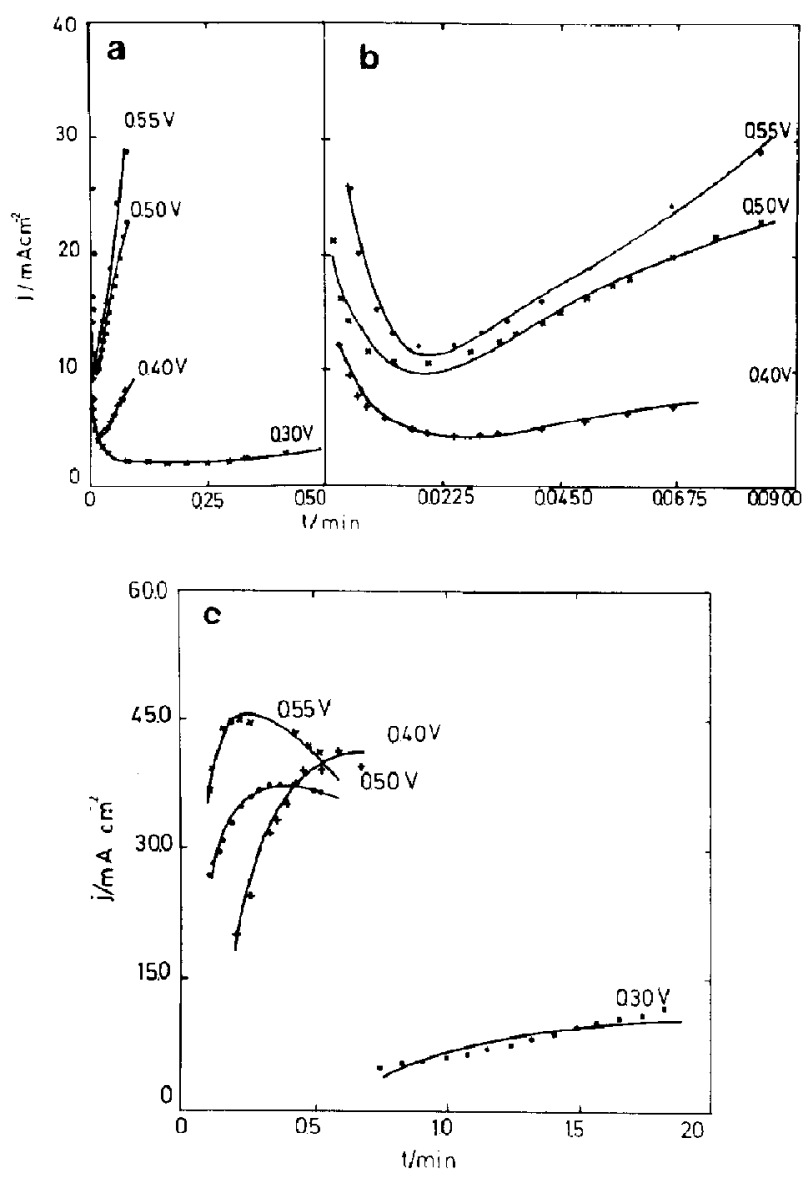

Fig. 10. (a) Initial part of the current transients in the borax buffer $+0.5 \mathrm{M} \mathrm{NaCl}$ solution at different $E_{\text {a }}$ values; (b) detail of the initial part of current transients. $(O \square+x)$ experimental data, $(-)$ computed from Equations (17), (27) and (30); (c) current maximum of transients $(\varphi, x, \boldsymbol{a},+)$ experimental data, $(-)$ computed from Equation (33).

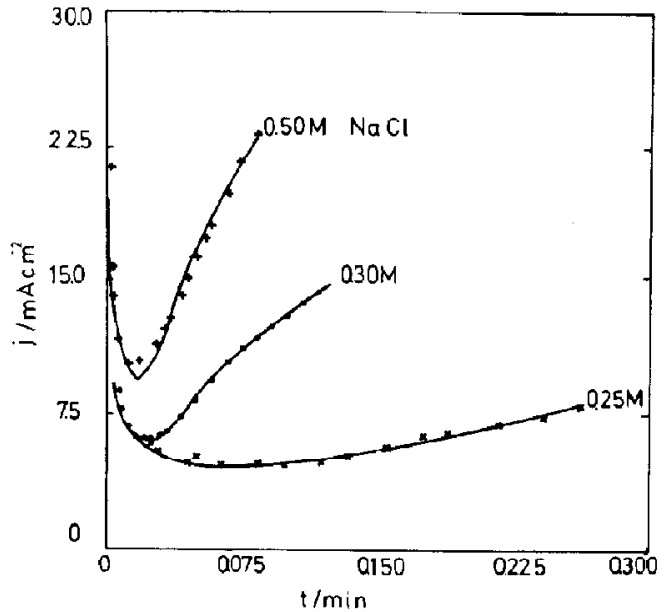

Fig. 11. Current transients recorded in borax buffer $+x M$ $\mathrm{NaCl}$ solutions at $E_{s}=0.5 \mathrm{~V}$. ( $(\square, x,+)$ experimental data $\left(\longrightarrow\right.$ computed from Equations (17), (27) and (30); $25^{\circ} \mathrm{C}$.

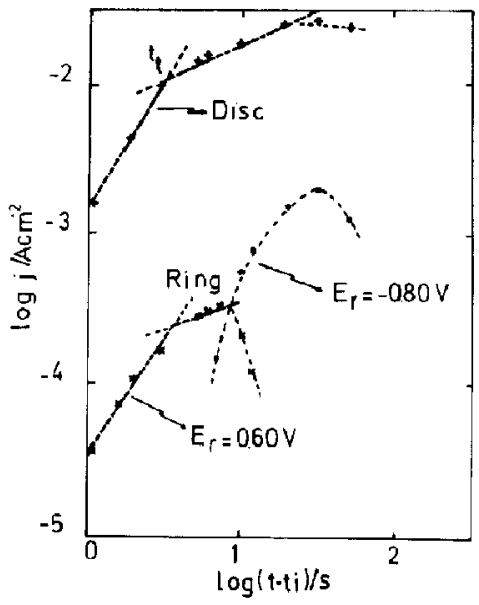

Fig. 12. Log $j$ os $\log \left(t-t_{i}\right)$ plots. Total current density at the rotating disc electrode $(+) E_{a}=0.50 \mathrm{~V}, \omega=250 \mathrm{rpm}$, borax buffer $+0.5 \mathrm{M} \mathrm{NaCl}$ solution; $j_{1}(\mathrm{x}) E_{\mathrm{r}}=0.60 \mathrm{~V}$; $j_{\text {II }}\left(\right.$ G) $E_{\mathrm{r}}=0.80 \mathrm{~V}$. 


\section{DISCUSSION}

The anodic current potential curve of polycrystalline copper in weak alkaline buffers containing $\mathrm{NaCl}$ can be divided into at least three potential regions. This division is useful for rationalizing the discussion of results. In the $E_{A_{\mathrm{I}^{\prime}}} \leqq E_{s} \leqq E_{A_{11}}$ potential range (region I) the formation of a hydrous anodic layer involving $\mathrm{Cu}_{2} \mathrm{O}, \mathrm{Cu}(\mathrm{OH})_{2}$ and a certain amount of $\mathrm{CuCl}$ takes place. This layer apparently involves an inner and outer layer complex structure[4]. At $E_{s}>E_{A_{U}}$ a passive region extending up to $E_{b}$ is observed (region II) and at $E_{s}>E_{b}$ pitting corrosion by the aggressive chloride ions is accomplished (region III).

\section{Interpretation of the electrochemical reactions}

1.1. Analysis of region $\mathrm{I}$. In the absence of $\mathrm{NaCl}$ the early stage of copper electrooxidation is interpreted as the electroformation of a $\mathrm{Cu}(\mathrm{OH})_{\text {ad }}$ monolayer on copper through the underpotential decomposition (UPD) of water yielding absorbed $\mathrm{OH}^{-}$species[17]. This reaction sccurring at $F_{s}$ values lower than the equilibrium potential of the $\mathrm{Cu} / \mathrm{Cu}(\mathrm{I})$ reversible electrode (Table 1) is followed as $E_{s}$ becomes closer to $E_{A_{\mathrm{L}}}$ by the tridimensional growth of the hydrous $\mathrm{Cu}_{2} \mathrm{O}$ layer. Both soluble $\mathrm{Cu}(\mathrm{I})$ and $\mathrm{Cu}(\mathrm{II})$ species are detected at this stage of copper anodization in alkaline electrolytes[5]. When $E_{s}$ approaches $E_{A_{11}}$ the electroformation of the hydrous $\mathrm{Cu}(\mathrm{OH})_{2}$ layer takes place[4]. In this way, the complex anodic layer structure involving the inner $\mathrm{Cu}_{2} \mathrm{O}$ and outer $\mathrm{Cu}(\mathrm{OH})_{2}$ layer is built. In the presence of $\mathrm{NaCl}$, the increase with $c_{\mathrm{NaCl}}$ of both the current density required for the tridimensional passive film growth and the amount of soluble $\mathrm{Cu}(\mathrm{I})$ suggests the prevalence of copper chlorocomplex electrodissolution over the $\mathrm{Cu}_{2} \mathrm{O}$ electroformation. The formation of a certain amount of $\mathrm{CuCl}$ at $E_{A_{1}} \leqq E_{s} \leqq E_{A_{I I}}$ on the $\mathrm{Cu}_{2} \mathrm{O}$ layer correlates with both the appearance of peak $A_{\text {III }}$ and the thermodynamic data assembled in Table 1. Then, the structure of the anodic layer can be represented by a poorly hydrous inner $\mathrm{Cu}_{2} \mathrm{O}$ non-homogeneously covered by $\mathrm{Cu}(\mathrm{OH})_{2}$ and $\mathrm{CuCl}$ precipitates. These results can be interpreted through a series of competitive adsorption reactions, involving $\mathrm{Cl}^{-}$and $\mathrm{OH}^{-}$ions at the copper surface, according to the following simple chemical formalism:

$$
\begin{gathered}
\mathrm{Cu}+\mathrm{H}_{2} \mathrm{O} \rightarrow \mathrm{Cu}(\mathrm{OH})_{\mathrm{ad}}+\mathrm{H}^{+}+e^{-} \\
\mathrm{Cu}+\mathrm{OH}^{-} \rightleftharpoons \mathrm{Cu}(\mathrm{OH})_{\mathrm{ad}}+e^{-} \\
\mathrm{Cu}+\mathrm{Cl}^{-} \rightleftharpoons \mathrm{Cu}(\mathrm{Cl})_{\mathrm{ad}}+e^{-} \\
\mathrm{Cu}(\mathrm{Cl})_{\mathrm{ad}}+\mathrm{OH}^{-} \rightleftharpoons \mathrm{Cu}(\mathrm{OH})_{\mathrm{ad}}+\mathrm{Cl}^{-} \\
\mathrm{Cu}(\mathrm{OH})_{\mathrm{ad}}+\mathrm{Cl}^{-} \rightleftharpoons \mathrm{Cu}(\mathrm{Cl})_{\mathrm{ad}}+\mathrm{OH}^{-} \\
\mathrm{Cu}(\mathrm{OH})_{\mathrm{ad}}+\mathrm{OH}^{-} \rightleftharpoons \mathrm{Cu}(\mathrm{OH})_{2}^{-} \\
\mathrm{Cu}(\mathrm{Cl})_{\mathrm{ad}}+\mathrm{Cl}^{-} \rightleftharpoons \mathrm{CuCl}_{2}^{-} .
\end{gathered}
$$

Reaction (6) is the UPD decomposition of water yielding adsorbed $\mathrm{OH}^{-}$. This reaction occurs as a reversible process at the monolayer level[17]. Reactions (7) and (8) correspond to anion adsorption processes. Reactions (9) and (10) indicate competitive adsorption stages and reactions (11) and (12) are related to copper electrodissolution through soluble $\mathrm{Cu}(\mathrm{I})$ species.

The second level of copper electrooxidation can follow, in principle, both pathways either through $\mathrm{Cu}(\mathrm{OH})_{\text {ad }}$ or through $\mathrm{Cu}(\mathrm{Cl})_{\text {ad }}$ species:

$$
\begin{aligned}
& \mathrm{Cu}(\mathrm{OH})_{\mathrm{ad}} \rightarrow \text { oxide (i) } \\
& \mathrm{Cu}(\mathrm{Cl})_{\mathrm{ad}} \rightarrow \mathrm{CuCl} \text { (i). }
\end{aligned}
$$

The composition and structure of the tridimensional layer should change according to the relative contribution of reactions (13) and (14). The relative amount of adsorbed $\mathrm{OH}^{-}$and $\mathrm{Cl}^{-}$ions should depend on the local $\mathrm{pH}$ value which is mainly determined by reaction (6). Thus, when copper is in contact with concentrated $\mathrm{NaCl}$ acid solutions the anodic reaction yields $\mathrm{CuCl}_{2}^{-}$ or $\mathrm{CuCl}_{3}^{2-}$ (at $c_{\mathrm{NaCl}}<0.7 \mathrm{M}$ and $c_{\mathrm{NaCl}}>0.7 \mathrm{M}$, respectively) and a $\mathrm{CuCl}$ precipitate[18] as reaction products, although in the borax buffer $(\mathrm{pH} 9.00) \mathrm{Cu}_{2} \mathrm{O}$ electroformation is thermodynamically favoured. Therefore, in the latter case copper undergoes electrodissolution through a thin $\mathrm{Cu}_{2} \mathrm{O}$ layer and $\mathrm{CuCl}$ deposition results on the $\mathrm{Cu}_{2} \mathrm{O}$ film. In this case, the dependences of the current peaks on $\omega$ suggest that $\mathrm{Cu}_{2} \mathrm{O}$ and $\mathrm{CuCl}$ electroformations are controlled by diffusion [18].

1.2. Analysis of region $I I$. In the borax buffer and in the borax buffer $+x \mathrm{M} \mathrm{NaCl}$ solutions, the passive current density $(j)$ involves two main contributions, namely the current density associated with the passive layer $\left(j_{p}\right)$ and that related to the copper electrodissolution through the passive layer $\left(j_{c}\right)[19]$. In this potential region under stationary conditions $j_{p} \rightarrow 0$ and $j \rightarrow j_{c}$. The contribution of $j_{\varepsilon}$ which is related to the formation of soluble $\mathrm{Cu}(\mathrm{II})$ increases with $c_{\mathrm{NaCl}}$, as expected from the fact that the formation of $\mathrm{CuCl}^{+}$ soluble species is assisted by increasing $c_{\mathrm{NaCl}}$ in solution.

1.3. Analysis of region $I I I$. In NaCl-containing solutions with prepassivated copper electrodes, both the potentiostatic current transients and the voltammograms are typical of those expected for the nucleation and growth of a new phase on the electrode[20]. Both EDAX and SEM data indicate that $\mathrm{CuCl}$ appears at local points related to pitting corrosion of prepassivated copper. The increase of $E_{b}$ with $\omega$ can be regarded as the salt nuclei stabilization caused either by removal of chloro-complexes out of the reaction region or localized acidification[21].

The mechanism of pitting corrosion of prepassivated copper in $\mathrm{NaCl}$ solutions can be conceived as a sequence of stages involving the initial nucleation of $\mathrm{CuCl}$ at weak points and defects of the $\mathrm{Cu}_{2} \mathrm{O}$ layer (stage 1) followed by salt nuclei penetration through the inner $\mathrm{Cu}_{2} \mathrm{O}$ layer to reach the metal oxide interface (stage 2). The induction time $\left(t_{i}\right)$ is related to stages 1 and 2[22]. The following stages are the direct attack of the base copper metal covered either by a discontinuous thin chloride phase (stage 3 ) or by the thick $\mathrm{CuCl}$ salt layer formed by precipitation (stage 4). The corresponding reactions imply the local formation of different ionic soluble complexes such as $\mathrm{CuCl}_{2}^{-}$and $\mathrm{CuCl}_{3}^{2-}$ in equilibrium with $\mathrm{CuCl}$ and $\mathrm{CuCl}_{2}^{-}$(sat). The presence of soluble $\mathrm{Cu}(\mathrm{II}) \mathrm{can}$ be explained through the following reaction at the salt covered regions, involving $\mathrm{CuCl}[12]$.

$$
\mathrm{CuCl} \rightleftharpoons \mathrm{Cu}^{2+}+\mathrm{Cl}^{-}+\mathrm{e}^{-} .
$$


2. A generalized model for the anodic behaviour of prepassivated copper

The kinetic characteristics of the various processes involved in the anodization of prepassive copper in $\mathrm{NaCl}$ solutions can be estimated through the analysis of the potentiostatic current transients run in different potential ranges. Thus, the instantaneous average anodic current $\left(I_{i}\right)$ is assigned to three main processes, namely the passive layer growth $\left(I_{p}\right)$, the metal corrosion through the passive layer $\left(I_{c}\right)$ and the random salt nuclei growth on the metal surface $\left(I_{s}\right)$ :

$$
I_{t}=I_{p}+I_{c}+I_{s} \text {. }
$$

Neglecting the contributions from the changes in the electrical double layer structure, in the absence of pitting. $I_{y}$ and $I_{*}$ become the most important contributions to $I_{s}$. The growth of the passive layer on the prepassivated copper can be regarded as the formation of a new phase following an instantaneous nucleation and circular bidimensional growth mechanism under diffusion control. In this case, considering that the passive layer growth and the corrosion current are independent and separate processes occurring on the whole electrode surface, the rate equation in terms of the apparent current density is[23]:

$$
j_{p}=P_{1} \exp \left(-P_{2} t\right)
$$

where $P_{1}=q_{\operatorname{mon}} \pi K_{e} D N_{0} ; P_{2}=K_{e} \pi D N_{0} ; D$ is the diffusion coefficient of the reacting species; $q_{\text {mon }}$ is the charge density required for the full coverage of the metal surface by the constant thickness passive layer; $K_{e}$ is a proportionality constant and $N_{0}$ is the number of sites available for nucleation.

On the other hand, the rate of metal corrosion through the passive layer appears as the dissolution of tridimensional nuclei under diffusion control following a rate equation of the form[24]:

$$
j_{c}=\frac{P_{3}}{\sqrt{ } t}\left[1-\exp \left(-P_{4} t\right)\right]
$$

where $P_{3}=2 F D^{1 / 2} \Delta c / \pi^{1 / 2}$ and $P_{4}=K_{q} \pi N_{0}^{\prime} D^{\prime}$. $\Delta c$ is the concentration difference of the diffusing species and $N_{0}^{\prime}$ is the number of sites available for the dissolution process. In the absence of pitting Equations (17) and (18) with the set of parameters assembled in Table 3 reproduce satisfactorily the current transients [Figs 7(a)-(b)]. Obviously, the time scale associated with $j_{p}$ and $j_{c}$ are considerably different. The contribution of the latter principally manifests for $t<2 \mathrm{~s}$, but as $t \rightarrow \infty j_{c} \rightarrow j_{t}$. As no influence of solution stirring is observed, the second laycr growth on the prepassivated copper specimen should involve a rate process in the solid phase such as the diffusion of either anion or cation or both through the $\mathrm{Cu}_{2} \mathrm{O}$ layer. In the $0.2 \leqq E_{s} \leqq 0.8 \mathrm{~V}$ range the values of $q_{\text {mon }}$ obtained from $P_{1} / P_{2}$ ratio are between 0.8 and $6 \mathrm{mC} \mathrm{cm}^{-2}$. Otherwise, the $q_{\text {mon }}$ vs $E_{\mathrm{s}}$ plot coincides reasonably well with recently reported data resulting from potentiodynamic reduction of copper in borax solutions (Fig. 13)[14]. Moreover, the average thickness of the passive layer formed at $E_{s}$ can be estimated from the equation:

$$
\boldsymbol{h}=\frac{M}{z \rho F}\left(q_{\mathrm{mon}}\right)_{\mathrm{Cu}_{2} \mathrm{O}}
$$

where $M$ is the molecular weight and $\rho$ is the density of the layer.

Considering that at low potentials the passive layer consists mainly of $\mathrm{Cu}_{2} \mathrm{O}$, then for $M=95.54 \mathrm{~g} \mathrm{~mol}^{-1}$, $\rho=3.29 \mathrm{~g} \mathrm{~cm}^{-3}$ and $q_{\text {mon }}=0.8 \mathrm{mC} \mathrm{cm}^{-2}$ it results $h$ $=11 \mathrm{~A}$.

As for $E_{s}>E_{A_{11}}$ the charge of the inner $\mathrm{Cu}_{2} \mathrm{O}$ becomes potential independent [4]; the charge related to the outer hydrous $\mathrm{CuO}$ layer can be estimated from the following difference:

$$
\left(q_{\text {mon }}\right)_{\mathrm{CuO}}=\frac{P_{1}}{P_{2}}-\left(q_{\text {mon }}\right)_{\mathrm{Cu}_{2} \mathrm{O}}
$$

Taking $\left(q_{\text {mon }}\right)_{\mathrm{Cu}_{2} \mathrm{O}}=0.8 \mathrm{mCc^{-2 }}$, for a water-free CuO layer $M=79.54 \mathrm{~g} \mathrm{~mol}^{-1}$ and $\rho=6.41 \mathrm{~g} \mathrm{~cm}^{-3}$, in the $0.40 \leqq E_{s} \leqq 0.80 \mathrm{~V}$ the resulting thickness for the outer layer is between 4.8 and $33 \AA$. On the assumption that the outer layer consists of $\mathrm{Cu}(\mathrm{OH})_{2}$, then for $M=97.54 \mathrm{~g} \mathrm{~mol}^{-1}$ and $\rho=3.36 \mathrm{~g} \mathrm{~cm}^{-3}$, the value of $h$ results in the $11-78 \AA$ range.

\begin{tabular}{|c|c|c|c|c|c|c|c|c|}
\hline$E_{\mathrm{s}} / \mathrm{V}$ & $P_{1} / \mathrm{mA} \mathrm{cm}^{-2}$ & $P_{2} / \min ^{-1}$ & $P_{3} / \mathrm{mA} \mathrm{min}^{1 / 2} \mathrm{~cm}^{-2}$ & $P_{4} / \min ^{-1}$ & $E_{r}$ & $P_{1 r} / \mathrm{mA} \mathrm{min}^{1 / 2} \mathrm{~cm}^{-2}$ & $P_{2 r} / \min ^{-1}$ & $P_{3 \mathrm{r}} / \mathrm{mA} \mathrm{cm}^{-2}$ \\
\hline \multicolumn{9}{|c|}{ Borate boric acid buffer } \\
\hline 0.20 & 0.691 & 52.3 & 0.0855 & 0.793 & -0.80 & 0.125 & 1.16 & 0.0261 \\
\hline 0.40 & 1.32 & 51.0 & 0.118 & 1.55 & & & & \\
\hline 0.60 & 3.95 & 55.7 & 0.347 & 4.26 & & & & \\
\hline 0.80 & 4.98 & 49.8 & 0.398 & 6.00 & & & & \\
\hline \multicolumn{9}{|c|}{ Borate-boric acid buffer $+0.5 \mathrm{M} \mathrm{NaCl}$} \\
\hline 0.20 & 6.47 & 43.7 & 1.07 & 61.5 & -0.80 & 0.249 & 1.94 & 0.0809 \\
\hline
\end{tabular}

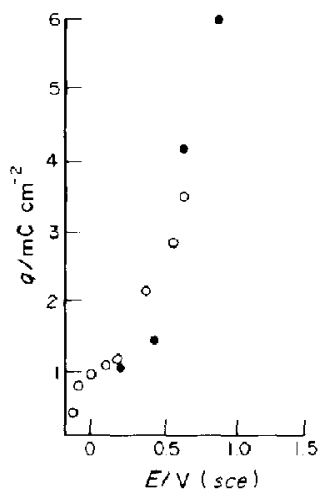

Fig. 13. Charge (q) us potential (E) plot. (o) data taken from ref. [4]; (๑) data calculated from Equation (17).

Table 3. Parameters used in simulation of potentiostatic current transients with Equations (17), (18) and with Equation (24) 
Further details of the mechanism of prepassivated copper corrosion can be envisaged by considering that the increase in $E_{s}\left(E_{s}>0.40 \mathrm{~V}\right)$ appears as a potential drop in the outer oxide layer. The electrical field strength $(\varepsilon)$ in the outer oxide layer depends whether this layer is assigned to $\mathrm{CuO}$ or $\mathrm{Cu}(\mathrm{OH})_{2}$. Thus, for $\mathrm{CuO}, \epsilon=1.3 \times 10^{6} \mathrm{~V} \mathrm{~cm}^{-1}$ and for $\mathrm{Cu}(\mathrm{OH})_{2}, \epsilon=0.6$ $\times 10^{6} \mathrm{~V} \mathrm{~cm}^{-1}$

On the basis of these values the rate of metal corrosion through the passive layer $\left(j_{c}\right)$ can be interpreted in terms of cation diffusion from the metal/film interface to the film/solution interface resulting in the dissolution at the metal/film interface[25]. From $\boldsymbol{P}_{\mathbf{3}}$, the difference in the cation concentration between the metal/film $\left(c_{o}\right)$ and the film/solution $\left(c_{h}\right)$ interfaces can be estimated. Thus, taking $D=1 \times 10^{-14} \mathrm{~cm}^{2} \mathrm{~s}^{-1}[26]$, $\Delta c$ values between 0.05 and $0.07 \mathrm{~mol} \mathrm{~cm}^{-3}$ are obtained at the lower potentials. As $\Delta \varepsilon$ is close to $10^{6} \mathrm{~V} \mathrm{~cm}^{-1}$ for a film of $20 \AA$ and the potential drop $(\phi)$ within the oxide film related to the ion transfer can be considered directly proportional to $\varepsilon$

$$
\phi=\varepsilon h,
$$

the $c_{0} / c_{h}$ concentration ratio can be estimated from $\phi$ according to the equation:

$$
\phi=\frac{k T}{z e} \ln \frac{c_{o}}{c_{h}}
$$

where $k$ is the Boltzman constant and $e$ is the elcctron charge. For $\varepsilon=10^{6} \mathrm{~V} \mathrm{~cm}^{-1}$ and $h=20 \mathrm{~A}$ the $c_{o} / c_{h}$ ratio comes out close to $10^{6}$. This means that $\Delta c \cong c_{0}$. Therefore, $K_{e}$ can be evaluated from the equation [20]

$$
K_{e}=\left(\frac{8 \pi c_{a} M}{\rho}\right)^{1 / 2}
$$

for $M=63.54 \mathrm{~g} \mathrm{~mol}^{-1}$ and $\rho=8.52 \mathrm{~g} \mathrm{~cm}^{-3}$, $K_{e}=2.99$. Furthermore, from this figure and $P_{4}=27 \mathrm{~min}^{-1}, \quad N_{0}^{\prime}$ results equal $5 \times 10^{12} \mathrm{~cm}^{-2}$ This value suggests that the metal surface involved in the corrosion process is in the order of a few percent of the total copper surface. The contribution of the copper electrodissolution through the anodic layer to $\mathrm{Cu}$ (II) soluble species can be followed through the current transient of copper electrodeposition at the ring electrode $\left(E_{r}=-0.80 \mathrm{~V}\right)$. This transient can also be fitted by an equation similar to Equation (18). Assuming that copper electrodeposition involves a progressive nucleation and tridimensional growth under diffusion control[20] and taking into account the background current at the ring gold electrode $\left(P_{r_{3}}\right)$, the corresponding rate equation becomes

$$
j_{(r)}=\frac{P_{1 r}}{\sqrt{t}}\left[1-\exp \left(-P_{2 r} t^{2}\right)\right]+P_{3 r} .
$$

Both contributions increase as the $c_{\mathrm{NaCl}}$ increases. Equation (24) fits the experimental data (Fig. 14) reasonably well with the set of parameters assembled in Table 3. These results confirm that the corrosion current through the passive film is considerably increased in the presence of $\mathrm{Cl}^{-}$ions.

In the borax buffer containing $\mathrm{Cl}^{-}$ions at $E_{s}$ $<E_{b}\left(E_{s}=0.20 \mathrm{~V}\right)$, the $P_{1} / P_{2}$ ratio gives a $q_{\text {mon }}$ value in the order of $8 \mathrm{mC} \mathrm{cm}^{-2}$ suggesting that due to the presence of the aggressive anion either a thicker film

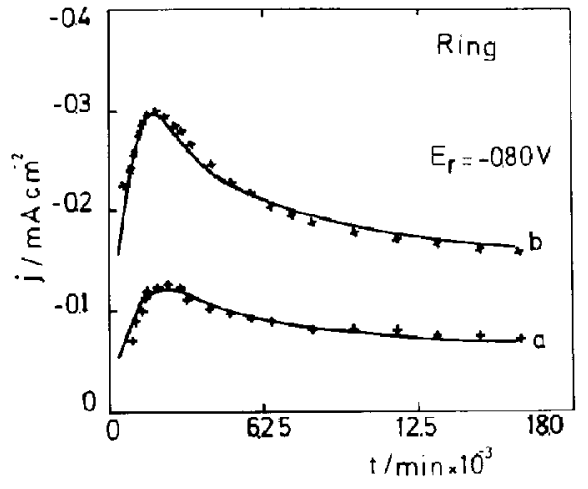

Fig. 14. Current at the rotating ring electrode by stepping the copper disc at $E_{3}(\omega=250 \mathrm{rpm})$. (a) borax buffer solution $E_{s}=0.20 \mathrm{~V}$; (b) borax buffer $+0.5 \mathrm{M} \mathrm{NaCl}$ solution, $E_{z}=0.20 \mathrm{~V} ; 25^{\circ} \mathrm{C}$. $(+)(x)$ experimental data, (-) computed from Equation (24).

probably containing $\mathrm{Cl}^{-}$ions as $\mathrm{CuCl}$ is formed or the corrosion area is enhanced. Microscopic observations reveal a certain increase in roughness of the electrode surface but this is insufficient to explain the increase in the $q_{\text {mon }}$ value. Furthermore, taking $c_{o}=0.05 \mathrm{~mol} \mathrm{~cm}^{-\frac{9}{3}}$, as obtained in the free chloride solution, the estimated apparent value of $D^{\prime}$ resulting in borax $+0.5 \mathrm{M} \mathrm{NaCl}$ at $E_{s}<E_{b}$ is close to 2 $\times 10^{-12} \mathrm{~cm}^{2} \mathrm{~s}^{-1}$, a figure which is two orders of magnitude greater than that resulting in the plain buffer solution. This considerable difference suggests that a layer thicker and more defective is formed in $\mathrm{NaCl}$-containing solutions. This may imply the inclusion of a CuCl layer into the oxide phase. This type of layer can be related to the current oscillations detected in the $E / j$ curves at $E_{s}<E_{b}$ (see Fig. 3) which are attributed to breakdown and repair events.

When $E_{s}>E_{b}$ localized corrosion of copper takes place when the direct contact between the $\mathrm{CuCl}$ salt layer and copper is established. This process involves an induction time which can be associated with the time required to complete the removal of the passive layer at defective points[22]. In this case, the contribution of $j_{c}$ can be expressed by the following equation

$$
j_{c}=\frac{P_{3}}{\sqrt{t}}\left[1.0-\exp \left(-P_{4} t\right)\right]+P_{5}\left[1.0 \exp \left(-P_{6} t^{2}\right)\right]
$$

The first term in Equation (25) is assigned to the corrosion of copper through the passive layer and the second one to the corrosion of copper at the passive film/growing salt nuclei interface. The latter process behaves as an instantaneous nucleation and conical growth under charge transfer control[27]. At $t_{i} \leqq t \leqq t_{t}$ it is reasonable to assume that most of the current is due to the second contribution[22], so that:

$$
P_{5}\left[1.0-\exp \left(-P_{6} t^{2}\right)\right] \geqslant \frac{P_{3}}{\sqrt{ } t}\left[1.0-\exp \left(-P_{4} t\right)\right]
$$

and then, Equation (25) becomes

$$
j_{c}=P_{5}\left[1.0-\exp \left(-P_{6} t^{2}\right)\right]
$$


Table 4. Parameters used in simulation of potentiostatic current transients with Equations (17), (27) and (30)

\begin{tabular}{cccccccc}
\hline$E_{s} / V$ & $P_{1} / \mathrm{mA} \mathrm{cm}^{-2}$ & $P_{2} / \mathrm{min}^{-1}$ & $P_{5} / \mathrm{mA} \mathrm{cm}^{-2}$ & $P_{6} / \mathrm{min}^{-2}$ & $P_{7} / \mathrm{mA} \mathrm{cm}^{-2}$ & $P_{8} / \mathrm{min}^{-2}$ & $t_{i} / \mathrm{s}^{-1.98}$ \\
\hline 0.30 & 5.56 & 24.8 & 1.98 & 124 & 4.42 & 3.68 & 12.8 \\
0.40 & 13.4 & 81.4 & 6.99 & 572 & 35.4 & 16.8 & 2.10 \\
0.50 & 21.9 & 74.7 & 15.9 & 808 & 72.2 & 18.6 & 0.530 \\
0.55 & 42.5 & 111 & 13.4 & 1400 & 97.2 & 28.6 & 0.250 \\
$c_{\mathrm{NaCl}} / \mathrm{M}$ & $P_{1} / \mathrm{mA} \mathrm{cm}^{-2}$ & $P_{2} / \mathrm{min}^{-1}$ & $P_{5} / \mathrm{mA} \mathrm{cm}^{-2}$ & $P_{6} / \mathrm{min}^{-2}$ & $P_{7} / \mathrm{mA} \mathrm{cm}^{-2}$ & $P_{8} / \min ^{-2}$ & $t_{t} / s$ \\
\hline 0.25 & 8.50 & 19.9 & 4.25 & 168 & 9.68 & 11.8 & 3.32 \\
0.30 & 11.7 & 53.9 & 11.1 & 453 & 24.7 & 24.9 & 2.52 \\
0.50 & 21.9 & 74.7 & 15.9 & 807 & 72.2 & 18.6 & 0.53 \\
\hline
\end{tabular}

where $P_{5}={ }_{2} F k_{3 c}^{\prime}$ and $P_{6}=\pi M_{3}^{2} k_{3 c}^{2} N_{0 s} / \rho_{s}^{2}, k_{3 c}$ and $k_{3 c}^{\prime}$ are formal rate constants for the nuclei growth in the directions parallel and perpendicular to the metal plane, respectively, $\rho$ is the salt $(\mathrm{CuCl})$ density whose molecular weight is $M_{s}$ and $N_{0 s}$ is the number of sites available for salt nuclei formation. When $t \rightarrow \infty$, Equation (27) becomes:

$$
j_{c}=P_{s}
$$

Equation (28) was previously used to describe the pitting behaviour of nickel and iron in the presence of different aggressive anions[15, 16]. In Equations (27) and (28) $j_{c}$ is an "apparent current density" related to local points where salt nuclei grow through the passive film. The passive layer can be totally removed at the sites of attack, which in turn become centres for another new phase formation, namely the nuclcation and growth of salt nuclei on the base copper. The rate of the latter process can also be represented as an instantaneous nucleation and conical growth under charge transfer control, according to the equation

$$
j_{s}=P_{7}\left[1.0-\exp \left(-P_{8} t^{2}\right)\right] .
$$

Obviously, $j_{s}$ is also an "apparent current density" related to the copper surface regions where pitting occurs. The expressions of $P_{7}$ and $P_{8}$ are similar to those of $P_{5}$ and $P_{6}$, respectively. When salt nuclei formation implies an induction time $\left(t_{i s}\right)$ Equation (29) becomes

$$
j_{s}=P_{7}\left\{1.0-\exp \left[-P_{8}\left(t-t_{i}\right)^{2}\right]\right\} .
$$

The current transients resulting for $E_{s}>E_{b}$ [Figs 10(a), (b), 11] are reproduced within $5 \%$ as maximum error, with Equations (17), (27), (30) using the parameters assembled in Table 4.

The potential dependence of $\boldsymbol{P}_{5}, \boldsymbol{P}_{6}$ and $\boldsymbol{P}_{7}$, $P_{8}$ approaches linear semilogarithmic relationships with slopes $\mathrm{d} E / \mathrm{d} \ln P_{5}=0.22 \mathrm{~V}, \mathrm{~d} E / \mathrm{d} \ln P_{6}=0.30 \mathrm{~V}$, $\mathrm{d} E / \mathrm{d} \ln P_{7}=0.18 \mathrm{~V}, \mathrm{~d} E / \mathrm{d} \ln P_{8}=0.08 \mathrm{~V} /$ decade, respectively. The slopes $\mathrm{d} E / \mathrm{d} \ln P_{7}$ and $\mathrm{d} E / \mathrm{d} \ln P_{\mathrm{B}}$ are likely to be related to the activated electrodissolution of copper at the surface, where the chloride salt layer impedes the repassivation of copper. This conclusion agrees with previous kinetic studies on copper electrodissolution in aqueous chloride solutions [6].

Equations (29) and (30) after series expansion yield the following relationships:

and

$$
j_{s}=P_{7} P_{8} t^{2}
$$

$$
j_{s}=P_{7} \boldsymbol{P}_{\mathrm{g}}\left(t-t_{\mathrm{is}}\right)^{2}
$$

which correspond to particular cases of the EngellStolica equation where $b=2.0$. This value of $b$ is approached at the initiation of pitting (Fig. 12).

The change in the kinetics of pit growth at $t \cong t_{\text {t }}$ which is accompanied by a decrease in $b$ can be related to the precipitation and spread of a thick $\mathrm{CuCl}$ layer on the metal surface. Secondary breakdown of this layer results in copper electrodissolution as $\mathrm{Cu}^{2+}$ leading to the precipitation of $\mathrm{CuCl}_{2}$. Then, an outer $\mathrm{Cu}(\mathrm{OH})_{2}$ layer is also formed acting as a barrier to separate the electrolyte in the pit from the bulk electrolyte. The formation and growth of this complex layer can be represented by an instantaneous nucleation and tridimensional growth under diffusion control. The corresponding rate equation is:

$$
j_{t} \cong j_{s}=\frac{P_{9}}{\sqrt{t}}\left\{1.0-\exp \left[-P_{10}\left(t-t_{\tau}\right)\right]\right\}
$$

where $P_{9}=z F D_{+}^{1 / 2} \Delta C_{+} / \pi^{1 / 2}$ and $P_{10}=\pi N_{0 s}^{\prime} K_{s} D_{+}$; $N_{0 s}^{\prime}$ denotes the number of sites available for salt precipitation inside the pits and $K_{s}$ is a proportionality constant.

When $P_{10}\left(t-t_{1}\right) \rightarrow \infty$, Equation (33) results:

$$
j_{s}=\frac{P_{9}}{\sqrt{t}} \text {. }
$$

The corresponding current transients[Fig. 10(c)] can be simulated with Equation (33) using the parameters assembled in Table 5. According to Equation (33) $t_{t}$ depends inversely on $j_{s}$, as is found experimentally.

According to the proposed kinetic model the current transient decay beyond $I_{M}$ is a consequence of $\mathrm{CuCl}_{2}$ formation and cation diffusion. Therefore, the value of $D_{+}$in Equation (33) can be estimated using $\Delta C_{+}$ $=3.31 \times 10^{-3} \mathrm{~mol} \mathrm{~cm}^{-3}$ from $\mathrm{CuCl}_{2}$ solubility $[28]$. and the following equation:

$$
D_{+}=\frac{P_{9} \pi^{1 / 2}}{2 F \Delta C_{+}} \text {. }
$$

Table 5. Parameters used in simulation of potentiostatic current transients with Equation (33)

\begin{tabular}{cccc}
\hline$E_{*} / \mathrm{V}$ & $P_{\mathrm{g}} / \mathrm{min}^{1 / 2} \mathrm{~mA} \mathrm{~cm}^{-2}$ & $P_{10} / \mathrm{min}^{-1}$ & $t_{\mathrm{t}} / \mathrm{s}$ \\
\hline 0.30 & 27.9 & 0.552 & 31.3 \\
0.40 & 42.9 & 2.83 & 8.12 \\
0.50 & 32.0 & 3.55 & 1.39 \\
0.55 & 30.3 & 6.55 & 2.19 \\
\hline
\end{tabular}


The $D_{+}$values are between $1.4 \times 10^{-6} \mathrm{~cm}^{2} \mathrm{~s}$ and 3.4 $\times 10^{-6} \mathrm{~cm}^{2} \mathrm{~s}^{-1}$ in reasonable agreement with values of the diffusion coefficient of ions in aqueous concentrated solutions.

Acknowledgements-INIFTA is a Research Institute jointly established by the Universidad Nacional de La Plata, the Consejo Nacional de Investigaciones Científicas y Técnicas and the Comisión de Investigaciones Científicas de la Provincia de Buenos Aires. D. V. M. acknowledges the fellowship granted by the Deutscher Akademischer Austauschdienst, through the University of MainzUniversity of La Plata Cooperation Agreement and the University of Concepción, Chile, for the leave of absence.

\section{REFERENCES}

1. Encyclopedia of Electrochemistry of the Elements, Vol. II (Edited by A. J. Bard). Marcel Dekker, New York (1976).

2. D. D. MacDonald, J. electrochem. Soc. 121, 651 (1974).

3. A. M. Castro Luna, S. L. Marchiano and A. J. Arvia, $J$. appl. Electrochem. 8, 121 (1978).

4. H. H. Strehblow and B. Titze, Electrochim. Acta 25, 339 (1980).

5. M. R. Gennero de Chialvo, S. L. Marchiano and A. J. Arvia, J. appl. Electrochem. 14, 165 (1984).

6. J. O'M. Bockris, B. T. Ruben, A. Despic and B. Lovrocek. Electrochim. Acta 17, 973 (1972).

7. C. H. Bontiglio, H. C. Albaya and O.A. Cobo, Corros. Sci. 13, 717 (1973).

8. F. M. Al-Kharafi and Y. A. El-Tantawy, Corros. Sci. 22, 1 (1982).

9. R. S. Cooper, J. electrochem. Soc. 103, 307 (1956)

10. R. S. Cooper, J. electrochem. Soc. 105, 109 (1958).
11. A. J. Calandra, N. K. de Taconi, K. Perejro and A. J. Arvia, Electrochim. Acta 19, 901 (1974).

12. R. K. Flatt and P. A. Brook, Corros. Sci. 11, 185 (1971).

13. J. Van Muylder, in Comprehensive Treatise of Electrochemistry (Edited by J. O'M. Bockris, B. E. Conway, E. Yeager and R. E. White), Vol. 4, p. 49, Plenum Press, New York (1981).

14. G. Faita, G. Fiori and D. Salvadore, Corros. Sci. 15, 383 (1975).

15. D. V. Vasquez Moll, R. C. Salvarezza, H. A. Videla and A. J. Arvia, J. electrochem. Soc. 132, 754 (1985).

16. D. V. Vasquez Moll, R. C. Salvarezza, H. A. Videla and A. J. Arvia, Corros. Sci. 24, 751 (1984).

17. S. Fletcher, R. G. Barradas and J. D. Porter, J. electruchem. Sue: 125, 19 G0 (1978),

18. L. Brossard, Corrosion 40, 420 (1984).

19. K. J. Vetter, Electrochim. Acra 16, 1923 (1971).

20. G. Gunawardena, G. Hills, I. Montenegro and B. Scharifker, J. electroanal. Chem, 138, 225 (1982).

21. J. R. Galvele, $J$ electrochem. Soc. 123, 464 (1976).

22. T. Okada, J. electrochem. Soc. 131, 241 (1984).

23. W. Davison and J. A. Harrison, J. electroanal Chem. 44, 213 (1973)

24. B. Scharifker and G. Hill, Electrochim. Acta 28, 879 (1983).

25. C. Y. Chao, L. F. Lin and D. D. MacDonald, J. electrochem. Soc. 129, 1187 (1981).

26. Z. Szklarska-Smialowska and W. Kozlowski, J. electrochem. Soc. 131, 234 (1984).

27. M. Y. Abyaneh and M. Fleichmann, Electrochim. Acta 27, 1513 (1982).

28. The Handbook of Chemistry and Physics (Edited by R. Weast). C. R. Press (1977).

29. Ken Nobe, L. L. C. Sorensen and W. D. Bjorndahl, Extended Abstracts 166th Society Meeting, Vol. 84 (1984). 